\title{
Strategies of Subtitling Swear words in The Wolf of Wall Street Movie
}

\author{
Asst. Prof. Zeineb Sami Hawel \\ Dept. of Translation/ College of Arts \\ Univ. of Basra/ Iraq
}

Abstract

Audiovisual translation ( AVT ), including subtitling, constitutes a fundamental part of Translation Theories and Translation Studies; however, it has been neglected till recent years. Gradually, a number of studies begun to appear especially those attributed to the European Association for Studies in Screen Translation. As these studies continually increase, new technologies and media forms became in a glare of publicity. These technologies and forms ,i.e. international and intercultural communications led to the emergence of new forms of translation. The most efficacious and widelyspread form is cinematography. The translation of cinematography works is called AVT. Scholars state ten kinds of AVT which can be united and classified into two main groups, i.e. subtitling and revoicing.

The present study concerns subtitling which generally means producing a dialogue translation in a film or an animated film in the form of titles usually appear at the bottom of the image or the screen . It attempts to shed light on subtitling( and in particular of swear words ) from English into Arabic in Terence Winter's The Wolf of Wall Street movie. It aims at investigating how the subtitler of this movie has dealt with these words in the original dialogue with the existence of the constraints imposed upon him. A quantitative analysis of the strategies used in subtitling the words and the number of those, the words, which have been changed through rendering, have been set to answer such a question.

Keywords: Subtitling, AVT, Swear words, taboo, Translation Strategies

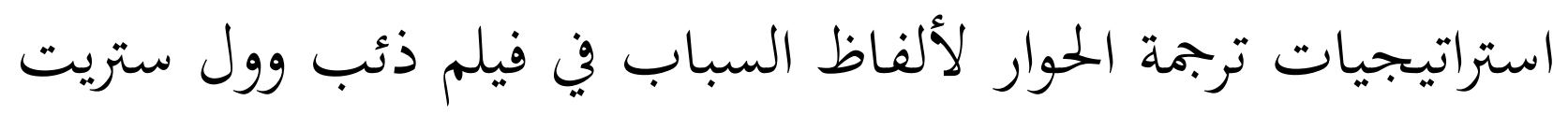

$$
\text { قأ.م التم زينب سامي حول كلية الآداب }
$$

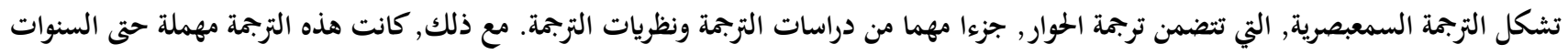

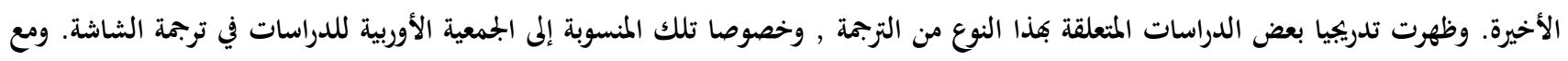

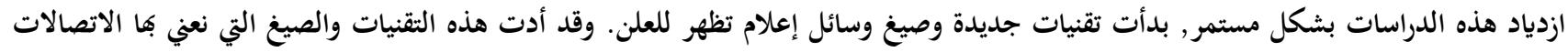

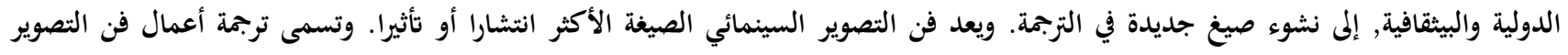

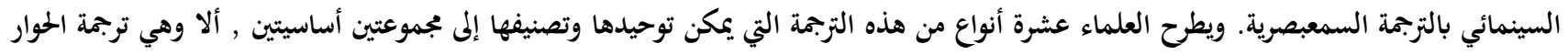

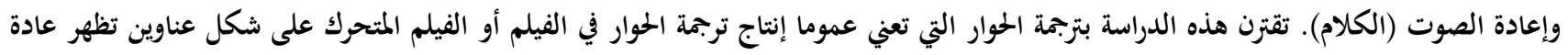

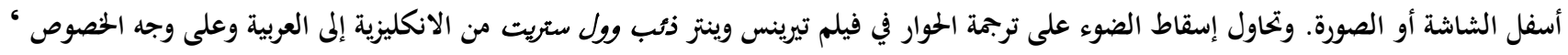

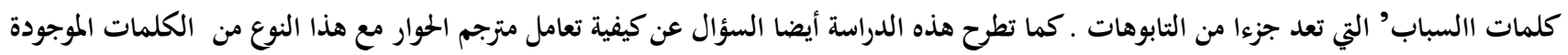


في حوار النص الأصلي مع وجود القيود المفروضة عليه. ولإجابة على هذا السؤال , تقدم هذه الدراسة تحليلا كميا للإستراتيجيات المستعملة في التزمة

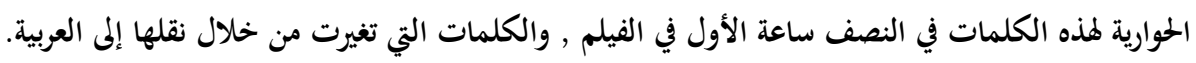

\section{Subtitling: Literature Review}

Chaume ( 2013: 112 ) defines subtitling as a process of integrating a written text in the target language (TL) on the screen where an original version film is shown under the approximate coincidence of the subtitles with the screen actors' dialogues. As regards the process of subtitling, Ivarsson and Carroll (1998: 79-80) state that the subtitler is usually provided with a script or a dialogue list in the source language (SL). In the best case $\mathrm{s} / \mathrm{he}$ gets a postproduction script which comprises the whole dialogue including the very badly audible parts if there are any. And, if s/he has good luck, s/he also has a glossary that includes explained dialect words, slang words/languages, local jokes, etc. . However, a special attention should be paid to the dialogue list since there may be some mistakes and discrepancies between this list and the actual film dialogue. Consequently, the subtitles must fit what is really being said. Hurt and Widler(1998: 261-63) mention that " subtitles usually appear and disappear in correspondence to original dialogue part and almost always are added to the image on the screen later as a result of post-production part." Ivarsson (1992) and Ivarsson and Carroll (1998) present the most comprehensive analysis of subtitles in a discussion of the high speed with which the human eye can read -although the average reading speed in the USA is 200-300 word per minute(wpm)-, these scholars reached to a fact that adults can read fasteradded to certain technical factors that allow more characters per line these days, " calling into question the empirical basis for current restrictions on space for subtitles(35 characters per line, average reading speed of $12 \mathrm{cps}$, etc.)". In addition to that, in a more comprehensive work, Diaz- Cintas and Remael claim that "Norms and conventions evolve quickly in subtitling and the advent of the DVD has been one of the major catalysts in the profession. As far as reading speed is concerned, 180 words per minute is increasingly becoming the norm in this new medium, with some companies applying even higher rates." (qtd. in Chaume 112).

It is said that translators face many constraints while translating a film. These constraints relate to the peculiarities of characters' speech in translating to the target audience. In this respect, Zubiria (2013: 9398) mentions that the most distinctive feature of most audiovisual products is the use of dialogues. The lively and spontaneous language of the latter makes the work of the translator more complicated. He adds that these dialogues, in turn, comprise some features that can be challenges for translators, like the frequent use of interjections and exclamations, rhymed scenes and different jokes, elliptical sentences, and grammatical deviations.

Added to the dialogues, he, Zubiria, advocates that characters also impose another constraints upon the translator since they constitute the verve of the most genres of cinematographical products. So, the first constraint it imposes is the names of these characters. Here the matter is that in some cases these names have their meanings which contain information about them, characters, or their lives. As a result, translators must find a suitable way to convey these additional meanings into the TL; otherwise the pragmatic effect may be partially lost.

In addition to the two constrains represented by the dialogues and the 
characters, Sonnensyn (2011: 96) adds another one. It lies in the creators of the films and with the language deviations. So, he says that the very often creators of films, and in particular animated cartoons, " colour the characters with different kinds of dialects, accents and slang to make them brighter, funnier and closer to ordinary people." Clearly, he means that the choice of dialects and/or accents is not randomly done; they are chosen according to the social stereotypes rooted in people's minds.Here he gives an example represented by Disney films. So, he says that " characters who are not very intelligent get South American dialect and negative characters usually get foreign speech characteristics. Higher percentage of characters who have foreign accents have negative roles than those who speak Standard American or British English."

In their works, following $\mathrm{R}$. Jacobson's classification of texts, Gottlieb (1998:244-48) and Reich (2006: 8-11) made their own classifications of subtitles dividing them into four groups, i.e. intralingual or vertical which change perceptive modality in that a spoken text is converted into a written one without any change of change; interlingual or diagonal which change both perceptive modality and language; open or non-optional represented which mean the integral physical part of the film or the tele programme; and closed or optional which are produced in the form of teletext that can be viewed by using a correspondent decoder.

In a study concerning the technical peculiarities of performance, D. Sanchez (2004) states four methods of subtitling, i.e. preliminary translationadaptation spotting; preliminary translation-spotting adaptation; adaptation-spotting-translation; translation/adaptation-spotting. Then he defines the term 'spotting' or 'timing' as the time marking according to which the film is divided into time parts, the beginning and the end of the phrase are marked.

It is clear then that the subtitler faces many problems and constraints while translating. Here
Lawrence Venuti's theory of Domestication and Foreignization must be mentioned. So, in his books The Translator's Invisibility: A History of Translation (1995) and The Scandals of Translation (1998) he clarifies that such a theory implies a question that demands knowing the extent of the translation's assimilation of the foreign text to the translated language and culture and how much this translation marks the differences of that text.

The studies mentioned above revealed subtitling, a branch of audiovisual translation, and the constraints the subtitlers may face while translating films and/or animated films or cartoons. To solve such a problem, certain strategies or procedures have been set to deal with the target text(TT), and then with the audience. This study attempts to investigate such a case, specifically, subtitling of swear words in The Wolf of Wall Street movie from English into Arabic, and the strategies followed by the subtitler of this movie.

\section{Swearing Defined}

As a natural part of any language, swearing is used regularly or in certain occasions by people in one way or another. Swear words denote taboo or stigmatized things in culture. These words should not be translated in a literal way.

They are used to express very strong emotions or attitudes. Such words constitute a crucial issue in translation. So, their scope is related to their functional aspect more than their meaning. To clarify the nature and definition of these words, let us begin with Oxford English Dictionary (1989: 376) which states that swearing is a term that is used " to utter a form of oath lightly or irreverently, as a mere intensive, or an expression of anger, vexation or other strong feeling, etc., to utter a profane 
oath, or use profane language habitually, more widely, to use bad language." In Concise Oxford Companion to the English Language (1998:924), it is defined as " a term that refers to both taking an oath and using language that is regarded as foul, abusive, and profane." Montague (2001: 56) affirms that such a phenomenon is a learned form of behaviour and not an innate instinct. Thus, he says that " swearing is not an innate instinct because it is a learned form of behaviour and a cultural response to certain conditions." Jay and Janschewitz (2008 : 267) talk about the connotative nature of swear words' meanings. They say that "The main purpose of swearing is to express emotions, especially anger and frustration. Swear words are well suited to express emotion as their primary meanings are connotative. The emotional impact of swearing depends on one's experience with culture and its language conventions."

It is observed that there is an interchangeable relation between taboos 'taboo words' and swear words. So, Migjord (2013 : 20-1) says that "swear words derive from so-called taboo areas in our lives, which is the reason why they have the power to offend, shock, persuade or assume, depending on the situation." Jay (2009: 155)clarifies the difference between the two in that " swear words function as a social and psychological phenomenon which personifies highly intense or inappropriately expressed emotions", " taboo words persist because they can intensify emotional communication to a degree that non-taboo words cannot."

It is worth mentioning that translating these words 'swear words' constitute a difficult task for translators. To solve such a problem, certain strategies can be applied to deal with them. This will be the topic of the following section:

\section{Strategies of Subtitling Swearwords}

It has been observed that the subtitler may face problems and imposed by certain constraints while translating a work. For this reason, s/he must seek the adequate strategy(ies) to overcome these problems. Krings (qtd. in Matkivska 42) says that the term strategy implies a narrow and abroad interpretation in Translation Studies discipline. Some scholars and theorists connect the concept 'strategy' with the concept 'problem'. Accordingly, "...translation strategy is viewed as a mechanism or method which is used to solve a particular problem in translating the original text. .... It is usually assimilated with translation technique or procedure." In this regard, Baker (1992)and Davies (2003) state a number of translation strategies to handle such a problem, i.e. softening, omission and literal translation. Hjort (2009) distinguishes two strategies in a study related to swearwords in subtitles and the problems the subtitler faces while translating these words, i.e. omission and mollification. Khalaf and Rashid (2016295-309) distinguish six strategies, i.e. deletion, register shift and the use of archaic words, change in the semantic field, the use of euphemistic expressions, generalization and linguistic substitution, and the use of ambiguous expressions. On his part, Federici (2011: 11) states two global or the so-called macro-strategies: standardization which means reducing the relevance and significance of language features, and adaptation, accounted as a creative impetus to solve the impasse in a completely different way. Bassnett and Lefevere (1990) present two microstrategies of adaptation, i.e. domestication and foreignization, which have been mentioned earlier. The first is based upon analogy as the 
simplest form of interaction between cultures. The second, as Venuti (1995) says, " is characterized by underlining and highlighting foreign identity of the text which removes the target culture to the background."

The present study investigates the strategies the subtitler has followed regards translating 'subtitling' the swear words in Terence Winter's The Wolf of Wall Street movie from English into Arabic. Before we begin with these strategies, let us state a brief synopsis about this movie:

\section{The wolf of Wall Street: A Brief Synopsis}

The wolf of Wall Street is an American movie which was produced in 2013, and directed by Martin Scorsese who is one of the most famous directors in America. This movie talks about Jordan Belfort who gets a job as a Wall Street stockbroker for L.F. Rothschild, played by Leonardo Di Caprio, who joins the stocks business by working under Mark Hanna, who was played by Matthew Mc Conaughey, and then he starts to establish his own company with his partner Donnie Azoff, played by Jonah Hill. His firm, Belfort's, Stratton Oakmont, becomes involved in rampant corruption and fraud on Wall Street that led to his downfall.

\section{Strategies of Subtitling Swearwords in The wolf of Wall Street : Data Analysis}

This section is devoted to investigating subtitling a number of shots that include swearwords during the first half of the first hour of the movie. These shots are classified in two tables according to the strategies followed by the subtitler to see how he has behaved towards these words as they are directed to Arab Muslim audience. The quantitative analysis shows that the subtitled swearwords vary in number in terms of the strategies used. The effect behind the use of each strategy is also discussed.

Table-1-

Strategies of Subtitling Swear words in The Wolf of Wall Street Movie:
(Deletion, Softening, and Addition)

\begin{tabular}{|c|c|c|c|}
\hline Strategy & TT & ST & $\begin{array}{l}\text { Timing } \\
\text { of } \\
\text { the } \\
\text { Movie }\end{array}$ \\
\hline $\begin{array}{l}\text { Softening: } \\
\text { Shit into } \\
\text { material }\end{array}$ & 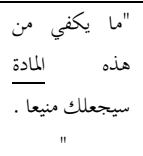 & $\begin{array}{l}\text { "Enough of this } \\
\text { shit }^{(2)} \text { will make } \\
\text { you invincible." }\end{array}$ & $\begin{array}{l}\text { 1. } 04: \\
36\end{array}$ \\
\hline $\begin{array}{l}\text { Deletion: } \\
\text { fucking }\end{array}$ & 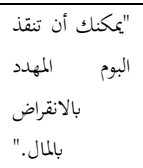 & $\begin{array}{l}\text { "You can save the } \\
\text { fucking spotted } \\
\text { owl with money." }\end{array}$ & 2. 05:07 \\
\hline $\begin{array}{l}\text { Deletion: } \\
\text { fucking }\end{array}$ & " "فهذا كل ما ستفله." & $\begin{array}{l}\text { "That's all you're } \\
\text { going to fucking } \\
\text { be doing." }\end{array}$ & $\begin{array}{l}3 . \\
06: 02\end{array}$ \\
\hline $\begin{array}{l}\text { Deletion: } \\
\text { fucking }\end{array}$ & حتى "ابتسم واتصل & $\begin{array}{l}\text { "Smile and dial } \\
\text { and don't pick } \\
\text { your fucking head } \\
\text { up till one." }\end{array}$ & 4. $06: 28$ \\
\hline $\begin{array}{l}\text { Deletion: } \\
\text { fucking }\end{array}$ & "يعجبني هذا." & $\begin{array}{l}\text { "I fucking love } \\
\text { that." }\end{array}$ & 5. $06: 43$ \\
\hline $\begin{array}{l}\text { Deletion: } \\
\text { fucking }\end{array}$ & أن إن كانت الأسهم يعرف & $\begin{array}{l}\text { "Nobody knows if } \\
\text { a stock's going up, } \\
\text { down or fucking } \\
\text { circles". }\end{array}$ & 6. $09: 56$ \\
\hline $\begin{array}{l}\text { Deletion: } \\
\text { fucking }\end{array}$ & "ليس حقيقيا." & $\begin{array}{l}\text { "It is not fucking } \\
\text { Real." }\end{array}$ & 7. $10: 14$ \\
\hline $\begin{array}{l}\text { Softening: } \\
\text { Shit into } \\
\text { anything }\end{array}$ & "نن لا نخلق أي & $\begin{array}{l}\text { "We don't create } \\
\text { shit." }\end{array}$ & 8. $10: 20$ \\
\hline $\begin{array}{l}\text { Deletion: } \\
\text { fucking } \\
\text { Deletion: } \\
\text { fucking }\end{array}$ & "وهو & $\begin{array}{l}\text { "He is all fucking } \\
\text { happy. } \\
\text { "Take his fucking } \\
\text { money and run } \\
\text { home." }\end{array}$ & $\begin{array}{l}9 . \quad 10: 27 \\
10 . \\
10: 29\end{array}$ \\
\hline $\begin{array}{l}\text { Deletion: } \\
\text { fucking }\end{array}$ & "وسيفعل في كل & $\begin{array}{l}\text { "He will every } \\
\text { single time because } \\
\text { he is fucking } \\
\text { addicted." }\end{array}$ & $\begin{array}{l}11 . \\
10: 45\end{array}$ \\
\hline Deletion: shit & 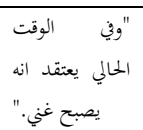 & $\begin{array}{l}\text { "Meanwhile he } \\
\text { thinks he is getting } \\
\text { shit rich." }\end{array}$ & $\begin{array}{l}12 . \\
10: 54\end{array}$ \\
\hline $\begin{array}{l}\text { Deletion: } \\
\text { fucking }\end{array}$ & "افعلها ل لأني & $\begin{array}{l}\text { "I do it because I } \\
\text { fucking need to." }\end{array}$ & 13. $11: 49$ \\
\hline $\begin{array}{l}\text { Deletion: the } \\
\text { fuck }\end{array}$ & توازنك." & $\begin{array}{l}\text { "Tip the fuck } \\
\text { over." }\end{array}$ & 14. $12: 19$ \\
\hline Deletion: shit & "أو الأسوأ." & "Or worst shit ." & $\begin{array}{l}15 . \\
12: 20\end{array}$ \\
\hline $\begin{array}{l}\text { Deletion: god } \\
\text { damn }\end{array}$ & "كل قرن." & $\begin{array}{l}\text { "Every god damn } \\
\text { century." }\end{array}$ & $\begin{array}{l}16 . \\
13: 06\end{array}$ \\
\hline
\end{tabular}


مجلة لارك للفلسفة واللسانيات والعلوم الاجتماعية العدد (34) الاصدار 1- 7 - 2019 (ابحاث اللغة الانكليزية)

\begin{tabular}{|c|c|c|c|}
\hline $\begin{array}{l}\text { Softening: } \\
\text { Shit into little }\end{array}$ & "اجني القليل من & $\begin{array}{l}\text { "Earning } \\
\text { money." }\end{array}$ & $\begin{array}{l}17 . \\
14: 04\end{array}$ \\
\hline $\begin{array}{l}\text { Softening: } \\
\text { No shit into } \\
\text { no doubt } \\
\text { Softening: }\end{array}$ & "الأسود إنه الاثنين & $\begin{array}{l}\text { "They call it black } \\
\text { Monday no shit." }\end{array}$ & 18. $14: 52$ \\
\hline $\begin{array}{l}\text { Deletion: I } \\
\text { don't know } \\
\text { some fucking } \\
\text { country in } \\
\text { Europe to get } \\
\text { shit + } \\
\text { Fucking }\end{array}$ & يفعلون ما يريدون & $\begin{array}{l}\text { "I don't know } \\
\text { some fucking } \\
\text { country in Europe } \\
\text { to get shit, let them } \\
\text { do what they want } \\
\text { to fucking do." }\end{array}$ & $\begin{array}{l}19 . \\
15: 03\end{array}$ \\
\hline $\begin{array}{l}\text { Deletion : } \\
\text { shitty }\end{array}$ & كسمسار بورصة لي لئ & $\begin{array}{l}\text { "My first shitty day } \\
\text { as a broker." }\end{array}$ & 20. $15: 41$ \\
\hline $\begin{array}{l}\text { Deletion: } \\
\text { fucking }\end{array}$ & "كيف فعلت & $\begin{array}{l}\text { "How did you } \\
\text { fucking do that?" }\end{array}$ & $\begin{array}{l}21 . \\
21: 29\end{array}$ \\
\hline $\begin{array}{l}\text { Deletion: } \\
\text { fucking }\end{array}$ & "لديك سيارة & $\begin{array}{l}\text { "Oh you got a } \\
\text { fucking nice car." }\end{array}$ & $\begin{array}{l}22 . \\
22: 40\end{array}$ \\
\hline $\begin{array}{l}\text { Softening } \\
+ \text { +Deletion: } \\
\text { Get out of } \\
\text { here into } \\
\text { You are jesting } \\
\text { + deletion : the } \\
\text { fuck }\end{array}$ & "أنت تزح ." & $\begin{array}{l}\text { "Get the fuck out } \\
\text { of here." }\end{array}$ & $23.23: 37$ \\
\hline $\begin{array}{l}\text { Deletion: } \\
\text { fucking }\end{array}$ & "أنا التقيت لثوي & $\begin{array}{l}\text { "I just met this } \\
\text { fucking guy." }\end{array}$ & 24. $23: 37$ \\
\hline $\begin{array}{l}\text { Deletion: } \\
\text { fucking }\end{array}$ & $\begin{array}{l}\text { "لا تخبر سوزان } \\
\text { " }\end{array}$ & $\begin{array}{l}\text { "Don't fucking tell } \\
\text { Susan." }\end{array}$ & 25. $23: 38$ \\
\hline $\begin{array}{l}\text { Softening: } \\
\text { Shit into } \\
\text { things }\end{array}$ & "أشياء سخيفة." & "Some stupid shit." & 26. $23: 53$ \\
\hline $\begin{array}{l}\text { Softening: } \\
\text { Shit into } \\
\text { stupidities }\end{array}$ & "الناس السخات." & "People say shit." & 27. $23: 59$ \\
\hline $\begin{array}{l}\text { Softening: } \\
\text { Shit into } \\
\text { thing + } \\
\text { ) Addition( } \\
\text { Adاon }\end{array}$ & "شيء بقريك عن & $\begin{array}{l}\text { "Shit about you } \\
\text { and your cousin." }\end{array}$ & 28. $24: 07$ \\
\hline
\end{tabular}

\begin{tabular}{|c|c|c|c|}
\hline $\begin{array}{l}\text { Softening: } \\
\text { Shit into } \\
\text { things }\end{array}$ & 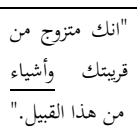 & $\begin{array}{l}\text { "You married } \\
\text { your cousin and } \\
\text { some stupid shit." }\end{array}$ & 29. $24: 15$ \\
\hline $\begin{array}{l}\text { Deletion: } \\
\text { fucking }\end{array}$ & "وكانت مثيرة & $\begin{array}{l}\text { "She was fucking } \\
\text { grow up hot." }\end{array}$ & 30. $24: 36$ \\
\hline $\begin{array}{l}\text { Deletion: } \\
\text { The shit out of }\end{array}$ & "القد أخفتني & $\begin{array}{l}\text { "You scared the } \\
\text { shit out of me } \\
\text { buddy." }\end{array}$ & 31. $25: 13$ \\
\hline $\begin{array}{l}\text { Deletion: } \\
\text { fucking }\end{array}$ & 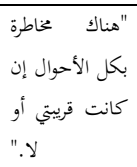 & $\begin{array}{l}\text { "There is a risk } \\
\text { whether she's } \\
\text { fucking your } \\
\text { cousin or not." }\end{array}$ & 32. $25: 17$ \\
\hline $\begin{array}{l}\text { Deletion: } \\
\text { fucking + } \\
\text { fucking }\end{array}$ & لا يوجد شخص سعيدا، & $\begin{array}{l}\text { "I'm not fucking } \\
\text { happy, no one's } \\
\text { married is fucking } \\
\text { happy." }\end{array}$ & 33. $25: 52$ \\
\hline $\begin{array}{l}\text { Deletion: } \\
\text { fucking }\end{array}$ & "أنا اشكر كلك العمل." & $\begin{array}{l}\text { "I really appreciate } \\
\text { this fucking job." }\end{array}$ & 34. $26: 01$ \\
\hline $\begin{array}{l}\text { Deletion: } \\
\text { fucking }\end{array}$ & "ماذا تفعل؟" & $\begin{array}{l}\text { "What are you } \\
\text { fucking doing? }\end{array}$ & 35. $26: 23$ \\
\hline $\begin{array}{l}\text { Deletion: } \\
\text { fucking }\end{array}$ & " & $\begin{array}{l}\text { "You got to } \\
\text { fucking try it." }\end{array}$ & 36. $26: 23$ \\
\hline $\begin{array}{l}\text { Deletion: the } \\
\text { fuck }\end{array}$ & "لاع احد هنا، & $\begin{array}{l}\text { "Oh, no one is } \\
\text { here get the fuck } \\
\text { here." }\end{array}$ & 37. $26: 28$ \\
\hline $\begin{array}{l}\text { Deletion: } \\
\text { fucking }\end{array}$ & من "يجب أن نزج & $\begin{array}{l}\text { "Let's go fucking } \\
\text { run." }\end{array}$ & 38. $27: 18$ \\
\hline $\begin{array}{l}\text { Deletion: the } \\
\text { fuck }\end{array}$ & "ابتعد من هنا." & $\begin{array}{l}\text { "Get the fuck out } \\
\text { of here." }\end{array}$ & $\begin{array}{l}39 \\
28: 31\end{array}$ \\
\hline $\begin{array}{l}\text { Softening: } \\
\text { The hidden } \\
\text { pronoun (you) } \\
\text { into the fuck }\end{array}$ & 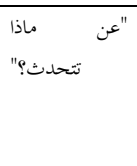 & $\begin{array}{l}\text { "What the fuck are } \\
\text { talking about?" }\end{array}$ & 40. $28: 58$ \\
\hline $\begin{array}{l}\text { Softening: } \\
\text { Give a shit } \\
\text { into care }\end{array}$ & لا لا بهل البوذيين... & $\begin{array}{l}\text { "Buddhists they } \\
\text { don't give a shit } \\
\text { about money." }\end{array}$ & 41. $29: 11$ \\
\hline $\begin{array}{l}\text { Deletion: } \\
\text { fucking }\end{array}$ & "بعني هذا & $\begin{array}{l}\text { "Sell me this } \\
\text { fucking pen right } \\
\text { here." }\end{array}$ & 42. $29: 40$ \\
\hline $\begin{array}{l}\text { Deletion: } \\
\text { fucking }\end{array}$ & "ستبيع شيء." & $\begin{array}{l}\text { "You fucking sell } \\
\text { anything." }\end{array}$ & $\begin{array}{l}43 . \\
29: 54\end{array}$ \\
\hline
\end{tabular}




\begin{tabular}{|c|c|c|c|}
\hline $\begin{array}{l}\text { Softening: } \\
\text { Shit into bad }\end{array}$ & "سميته السجادة & $\begin{array}{l}\text { "I call him a rag } \\
\text { because of his } \\
\text { piece of shit hair." }\end{array}$ & 44. $30: 39$ \\
\hline
\end{tabular}

\section{Analysis/Discussion}

It is clear that the above 44 shots show that the subtitler has employed three strategies of those mentioned in Section 3, while subtitling the swear words, i.e. deletion, softening, and addition. So, as subtitling is the translation' the written text' of the dialogue displayed on the screen for the audience, it must be taken into consideration that it must be presented in a way suitable for Arab Muslim audience. The matter of translating/ leaving swear words is crucial for the subtitler. The reason is that such a matter has two opposite sides. The first side lies in the bad language and subsequently bad effect if they are translated literally, while the second side lies in the subtitler's accusation of the translation poorness and incompletion when they are deleted in the TT since they represent the actor's actual case in which he is speaking. So, as far as the three strategies mentioned above are concerned, it is seen that deletion has the largest portion, including the following four categories of swear words :

- Sexual references, like fuck ;

- Profane or blasphemous, like god damn ; and

- Scatological or disgusting objects, like shit

The highest portion is that of the word fuck(ing). Then, there is the word shit(ty), and the least portion is that of the word (god damn), which is only one case.

If we look at all deleted words, it can be seen that all of them have no Arabic equivalence. And, though those words have been deleted, their contexts have been translated completely. In other words, the STs and TTs are identical semantically and syntactically. However, the subtitler's deletion of those words has lost the sense of swearing which reveals the writer's intention behind the situations in which they have been uttered.

Talking about the second strategy, i.e. softening, it has been found that it almost constitutes a quarter of the percentage of subtitling. The subtitler has softened and altered each one of them by the right equivalence according to the context. For example, 'shit' has been replaced by a number of parts of speech depending on sentence structure, like :

المادة , أي شيء, القليل, شك, أشياء, السخافات, أنت (ضمير مستتر), يهتم(ون),و السي (ئزة)

And, it has also been observed that each Arabic equivalence is suitable for the ST semantically and syntactically.

Addition, the third strategy followed by the subtitler, includes one case, i.e. 'زواجك' , an implied meaning in the ST.

Having stated subtitling the swear words via the three strategies, it is time to state the other strategies followed in subtitling the movie. This will be clarified in the following table :

Table-2-

\section{Register Shift and Change in the Semantic Field}

\begin{tabular}{|c|c|c|c|}
\hline $\begin{array}{l}\text { Timing } \\
\text { of } \\
\text { the } \\
\text { Movie }\end{array}$ & ST & TT & Strategy \\
\hline 1. $6: 15$ & $\begin{array}{l}\text { "A million } \\
\text { dollars? I could } \\
\text { only imagine } \\
\text { what a douchbag } \\
\text { that guy must } \\
\text { be." }\end{array}$ & لا لما يسعني أن أتخيل دولار.... الرجل & $\begin{array}{l}\text { Register shift: } \\
\text { Douchbag into } \\
\text { stupid }\end{array}$ \\
\hline 2. $6: 25$ & $\begin{array}{l}\text { " I see you } \\
\text { already met the } \\
\text { village asshole." }\end{array}$ & "ارٔى انك التقيت & $\begin{array}{l}\text { Register shift : } \\
\text { Asshole into } \\
\text { stupid }\end{array}$ \\
\hline 3. $6: 43$ & "Fuck him." & " تبا له." & Softening: \\
\hline
\end{tabular}




\begin{tabular}{|c|c|c|c|}
\hline & & & $\begin{array}{l}\text { Fuck into may } \\
\text { evil befall him! }\end{array}$ \\
\hline 4. $7: 04$ & $\begin{array}{l}\frac{\text { Fuck this, }}{\text { Shit }} \\
\text { that, } \text { C*k, }^{*} \text { C*nt, } \\
\text { Asshole." }\end{array}$ & "تبا. & $\begin{array}{l}\text { Softening: } \\
\text { Fuck into may } \\
\text { evil befall him! } \\
\text { Shit into may } \\
\frac{\text { evil befall him! }}{\text { And change in }} \\
\text { the semantic } \\
\text { field: } \\
\frac{\text { C*k }^{*} \text { into }}{\text { excrement }} \\
\frac{\text { prostituter }}{\text { Asshole into }} \\
\text { filthy into }\end{array}$ \\
\hline 5. $7: 16$ & $\begin{array}{l}\text { "Fuck face look } \\
\text { where the stocks } \\
\text { at today." }\end{array}$ & "أيها القبيح انظر & $\begin{array}{l}\text { Change in the } \\
\text { semantic field: } \\
\text { Fuck face into } \\
\text { ugly }\end{array}$ \\
\hline 6. $7: 16$ & $\begin{array}{l}\text { "Shut that } \\
\frac{\text { motherfucker }}{\text { shut it". }}\end{array}$ & "أغلق أغلقه." اللعين & $\begin{array}{l}\text { Register shift : } \\
\text { Motherfucker } \\
\text { into damned }\end{array}$ \\
\hline 7. 11:01 & $\begin{array}{l}\text { "We are taking } \\
\text { home cold heart } \\
\text { cash via } \\
\text { commission } \\
\text { motherfucker." }\end{array}$ & "نقن خلال العمولة ألمال نقدا & $\begin{array}{l}\text { Register shift : } \\
\text { Motherfucker } \\
\text { into } \\
\text { stupid }\end{array}$ \\
\hline 8. $15: 10$ & $\begin{array}{l}\text { "You know what } \\
\text { happened? A } \\
\frac{\text { fucking }}{\text { tsunami." }}\end{array}$ & "هل تعرث؟ تسو نامي ماذا & $\begin{array}{l}\text { Register shift : } \\
\text { Fucking into } \\
\text { damned }\end{array}$ \\
\hline 9. $15: 35$ & $\begin{array}{l}\text { "Holy fucking } \\
\text { shit." }\end{array}$ & "لعنة....لعناء." & $\begin{array}{l}\text { Register shift : } \\
\text { Holy fucking } \\
\text { shit into } \\
\text { Cursed damn }\end{array}$ \\
\hline 10. $17: 42$ & $\begin{array}{l}\text { "You cheap } \\
\text { fuck". }\end{array}$ & "أيها & $\begin{array}{l}\text { Register shift } \\
\text { and change in } \\
\text { the semantic } \\
\text { field: } \\
\text { Cheap fuck into } \\
\text { damned niggard }\end{array}$ \\
\hline 11. $18: 28$ & $\begin{array}{l}\text { "Come on who } \\
\text { buys this crap". }\end{array}$ & "هيا من يشتري & $\begin{array}{l}\text { Literal } \\
\text { translation: } \\
\text { Crap into } \\
\text { nonsense }\end{array}$ \\
\hline $12.24: 42$ & $\begin{array}{l}\text { "I'm not going to } \\
\text { let some one of } \\
\text { these assholes } \\
\text { fuck my cousin." }\end{array}$ & "فؤلاء الأوغاد لأي أن & $\begin{array}{l}\text { Change in the } \\
\text { semantic field : } \\
\text { Assholes into } \\
\text { the stupid } \\
\frac{\text { people }}{\text { softened }} \\
\text { translation: }\end{array}$ \\
\hline
\end{tabular}

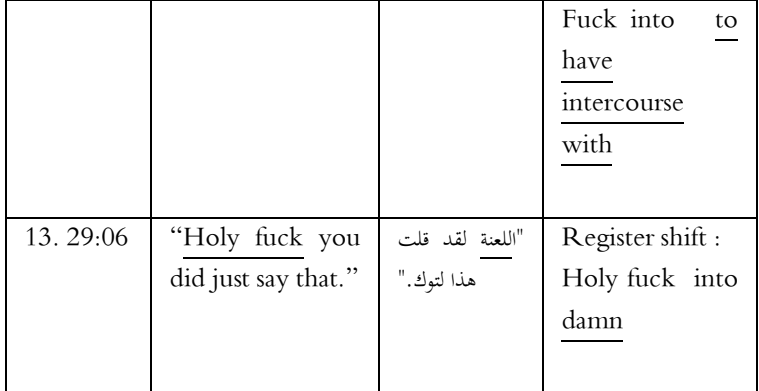

\section{Analysis/Discussion}

It is obvious that the above 13 shots vary in the strategies applied. The variety lies in register shift, softening, change in the semantic field and to a little extent, literal translation. In the first strategy, the subtitler has made a movement from the spoken style into the written one.

Khalaf and Rashid (2006 : 304-5) say that register shift " entails another change from the informal colloquial language variety in the movie to the formal standard variety in the subtitles." The employed diversity in subtitling from English into Arabic is Modern Standard Arabic (MSA).However, such a diversity may be unacceptable when subtitling into Arabic. For this reason, it must be replaced by more respectable variety of Arabic. So, the subtitler of the movie under study has used this shift as a way of lessening the indecency of some swear words when dealing with Arab audience. He has lowered the slang language into neutral. Thus, he has lowered the words : douchbag, asshole, motherfuck(er), fucking, Holy fucking shit, cheap fuck and Holy fuck into : وغدا, الوغد, اللعين, الوغد, لعين, لعنة ..لعناء, البخيل اللعين, واللعنة In addition to that, it is seen that there are cases in subtitling, i.e. softening, which is used, as it has been mentioned, to state the right 
equivalence according to the context in a milder manner, as in the cases :

تبا, تبا, غائط, العاهر, القذر , ويضاجعوا

Literal translation, addition and change in the semantic field are very few cases.

All in all, the above $(44+13)$ shots reveal that the subtitler of the movie has followed six strategies in subtitling those shots. Those strategies vary in number. The following table illustrates the frequency of each one of these strategies :

Table-3-

Frequency of Strategies of Subtitling Swear words in The Wolf of Wall Street

\begin{tabular}{|c|c|c|c|c|c|c|}
\hline \multicolumn{7}{|l|}{ Strategy } \\
\hline $\begin{array}{l}\text { Literal } \\
\text { Translat } \\
\text { ion }\end{array}$ & $\begin{array}{l}\text { Additi } \\
\text { on }\end{array}$ & $\begin{array}{l}\text { Chang } \\
\text { e in } \\
\text { the } \\
\text { Seman } \\
\text { tic } \\
\text { Field }\end{array}$ & $\begin{array}{l}\text { Regis } \\
\text { ter } \\
\text { Shift }\end{array}$ & $\begin{array}{l}\text { Soften } \\
\text { ing }\end{array}$ & $\begin{array}{l}\text { Deleti } \\
\text { on }\end{array}$ & $\begin{array}{l}\text { Word } \\
\text { Type }\end{array}$ \\
\hline- & - & 2 & - & 4 & 27 & fuck \\
\hline- & 1 & - & - & 10 & 4 & Shit(ty) \\
\hline- & - & - & 2 & - & - & $\begin{array}{l}\text { mothe } \\
\text { r } \\
\text { fuck(er } \\
\text { ) }\end{array}$ \\
\hline- & - & 1 & 1 & 1 & - & asshole \\
\hline- & - & 1 & - & 1 & - & $\mathbf{c}^{*} \mathbf{c k}$ \\
\hline- & - & 1 & - & 1 & - & $c^{*} n t$ \\
\hline 1 & - & - & - & - & - & crap \\
\hline- & - & - & 1 & - & - & $\begin{array}{l}\text { douchb } \\
\text { ag }\end{array}$ \\
\hline- & - & - & 4 & - & 1 & $\begin{array}{l}\text { god } \\
\text { (damn) }\end{array}$ \\
\hline 1 p.m. & 1 p.m. & 5 p.m. & $\begin{array}{l}8 \\
\text { p.m. }\end{array}$ & $\begin{array}{l}17 \\
\text { p.m. }\end{array}$ & $\begin{array}{l}32 \\
\text { p.m. }\end{array}$ & $\begin{array}{l}\text { Total }(6 \\
4) \\
\text { in the } \\
\text { first } 30 \\
\text { minutes }\end{array}$ \\
\hline
\end{tabular}

\section{Analysis/Discussion}

The above frequencies of the strategies followed in subtitling swear words show that the highest frequency or times is that of the strategy 'deletion'. In other words, the subtitler has avoided translating those words because of the bad effect they may cause on the audience. The softening strategy is the second. Here, the subtitler has tried to use adequate equivalences in the TT. Register shift strategy is the third. In such a strategy, the subtitler has changed the swear words from the informal colloquial language variety in the movie to the formal standard in the TT. The strategies change in the semantic field, addition and literal translation are the least in number.

\section{Conclusions}

The preceding sections of the present study are an attempt to show how the subtitler of The wolf of wall Street movie has dealt with the swear words. The concluding remarks the researcher has arrived at are stated in the following points:

1. Generally, the word 'swear' implies two meanings, i.e. taking an oath, and using profane language which belongs to what is called 'taboo(s)'.

2. In translating - in this study subtitling- the translator faces a number of difficulties when dealing with such words since they harm the target audience, due to their social, cultural, and religious beliefs.

3. It has been observed that subtitling the movie of this study shows that the subtitler has followed six strategies, i.e. deletion, softening, register shift, change in the semantic field, addition, and literal translation.

4. In general, translators follow deletion and softening strategies to reduce the bad effect of insulting and vulgar language; however, sometimes they tend to follow the literal translation strategy to make a similar effect on the target audience in certain cases.

5. The sample of this study shows that, as it has just been mentioned, the subtitler has followed the six mentioned strategies. The highest rate is attributed to the deletion strategy, then to 
softening, register shift, change in the semantic field, addition and literal translation respectively.

\section{Notes}

1. A taboo is a social, cultural, and/or religious custom that forbids people to do, use, touch or talk about certain things.

2. The underlines and the bold types of the words, phrases and sentences in the STs and TTs are the researcher's to pay the reader's attention to the changes in the process of subtitling.

\section{Bibliography}

[1] Baker, M. (1992) In Other Words: a Course book on Translation. London: Routledge.

[2] Bassnett, S. and A. Lefevere (1990) Translation, History and Culture (eds.) London: Printer.

[3] Chaume, Frederic (2013) 'The turn of audiovisual translation: New audiences and new technologies.' In Translation Spaces 2. John Benjamins Publishing Company.

[4] Davies, E. E. (2003) 'A Goblin or a Dirty Nose: The Treatment of Culture-specific References in Translations of Harry Potter Books.' In The Translator.

[5] Federici, F. M. (2011) 'Introduction: Dialects, idiolects, sociolects: Translation problems or creative stimuli?' In F. M. Federici (ed.), Translating Dialects and Languages of Minorities : Challenges and Solutions. Peter Lang, P.11.

[6] Gottlieb, H. (1998) 'Subtitling' In Baker, M.(ed.), Routledge Encyclopedia of Translation Studies. London and New York: Routledge, PP. 244-48.

[7] Hjort, M. (2009) ' Swearwords in Subtitles, A Balancing Act.' In The Translation of Dialects in Multimedia in TRAlinea. Available at: http://www.intralinea.org/

[8] Hurt, C. and Wilder, B. (1998) 'Untertitelung, Ubertitelung.' In Handbuch Translation. Tubingen: Stauffenburg, PP.261-63.

[9] Ivarsson, J.(1992) Subtitling for the Media. A Handbook of an Art. Stockholm:
[10] Ivarsson, Jan and Mary Carroll (1998) Subtitling. Simrishamn: TransEdit.

[11] Jay, T. (2009) ' The Utility and Ubiquity of Taboo Words.' In Perspectives on Psychological Science, Vol.4, No.2, PP.153-61.

[12] Jay, T. and K. Janschewitz (2008) ' The pragmatics of swearing.' In Journal of Psychology, No. 4, PP.267-88.

[13] Khalaf, Shahooth Abed and Sabariah Md Rashid (2016) ' Attenuating Obscenity of Swearing in the Amateur Subtitling of English Movies into Arabic.' In ArabWorld English Journal, Vol.7, No.1, PP. 295-309.

[14] McArthur, T. (1998) Concise Oxford Companion to the English Language. Oxford Oxford University Press.

[15] Migjord, Siri Margit (2013) ' Swearing in Subtitles.' In School of Business and Social Sciences. USA: Aahurst University.

[16] Montagu, A. (2001) The Anatomy of Swearing Philadelphia: University of Pennsylvania Press. Available at: http://books.google.com/books

[17] Oxford English Dictionary (2 ${ }^{\text {nd }}$ ed.) 1989. Oxford: Claredon Press.

[18] Reich, Pavel (2006) 'The Film and The Book in Translation.' Unpublished Diploma Thesis. Brno: Masaryk University.

[19] Sonnesyn, J. (2011) ' The Use of Accents in Disney's Animated Feature Films 1995 2009: A Sociolinguistic Study of the Good, the Bad and the Foreign.' Unpublished Master Thesis. Bergen: University of Bergen.

[20] The Wolf of Wall Street [On Line Movie]. Available at:

[21] https://www.shahidwbas.com/watch.php?vid=e71 fae0e3

[22] Venuti, L. (1995) The Translator's Invisibility: A History of Translation. London and New York: Routledge.

[23] . (1998) The Scandals of Translation: Towards an ethics of difference.

[24] London and New York: Routledge.

[25] Zubiria, Z. B. (2013) 'Mapping the Dubbing Scene: Audiovisual Translation in Basque Television.' In New Trends in Translation Studies. Peter Lang AG, Vol.2, PP. 93-98. 